\title{
o-(2-チアゾリルアゾ)フェノール誘導体によるコバルト(III) の定量*
}

\author{
川 瀬晃**
}

標記化合物は過ヨウ素酸カリウムなどの酸化剤の共存のもとでコバルトと反応して緑色のキレート化 台物堂生成する。乙のキレート化合物は水にかなり溶解するが，クロロホルムにはよく抽出される。 クロロホルム溶淮は, $600 \sim 700 \mathrm{~m} \mu$ ，および $400 \mathrm{~m} \mu$ 付近に極大吸収を有し，長波長側の波長におけ るモル财光係数は $1.5 \sim 2.5 \times 10^{4}$ 程度である.コバルト(II) キレートより感度は劣るが，極大吸収波長 の移動が大きく，他の金属イオンによる妨害が少ない.

NT 系の詓薬ではコバルト（III）として定量したほうがよい.

\section{1 緒言}

著者ら1) はさきにo-(2-チアゾリルアゾ) フェノール 類のキレート化合物の分析化学的応用について発表した が，その検討結果よりコバルト (III) の定量に適当であ ると考えられる 9 種類の試薬について定量方法を検討し た結果を報告する。

MMT，NT，MT，CTなどについては，イソアミル アルコールで抽出する方法をすでに発表したが2)，ここ では抽出溶媒にはクロロホルムを用いた。これらの試薬 はコバルト (III) と緑色の水溶性のキレート化合物を生 成する。こ机らのキレート化合物は SNT を除いてクロ ロホルム，イソアミルアルコールによく抽出される.ク 口ロホルム溶液は 600 700, $400 \mathrm{~m} \mu$ 付近に極大を有す る吸収曲線を示し，長波長側の極大吸収におけるモル吸 光係数は 1.5 2.5 $\times 10^{4}$ で，コバルト(II)より洁若干吸 光係数は小さいが極大吸収波長の移動は大きく，他の金 属による妨害も少ない，検討に使用した試薬は 9 種類 で，略記号は第 1 報1に示したものを用いた。

\section{2 試薬および装置}

標準コバルト溶液：高純度コバルト $0.5893 \mathrm{~g}$ を硝酸 $(1+1)$ 亿溶解し, 過塩素酸 $10 \mathrm{ml}$ を加元て白煙の発生す るまで加熱点発し, 水に溶解して $1 l$ とする.

この溶液 $10 \mathrm{ml}$ を $1 \mathrm{~g}$ の過ヨウ素酸カリウムを含む水 でうすめ, 正確に $1 l$ として使用する。 ての溶液は正確 に $10^{-4} M$ である。使用した試薬，装置は第 3 報1) と同 じで㐫る.

*o-(2-チアゾリルアゾ)フェノール誘導体の分析化学 的研究 (V)

** 科学技術庁金属材料技術研究所 : 東京都目黒区中目 黑 2 丁目
3 溶媒の選定

o-(2-チアゾリルアゾ) フェノール化合物吉.コバルト (III) と反応して緑色となる、緑色となる金属はパラジ ウムがあるのみで特徴のある呈色反応である.

このキレート化合物はニッケル，コバルト(II)，亜鉛 などのキレート化合物と異なり，かなり水に溶解する.

コバルトキレートは陽イオンの形で存在していると考 えられるので当然無極性溶媒には抽出されにくく, アル コール類, クロロホルムなどがよいと考えられる.

検討の結果は Table I に示した.

ベンゼン，四塩化炭素にはほとんど溶解しないキレー 卜も存在するので溶媒としては不適当である.MIBK, クロロホルム, イソアミルアルコールなどにはよく抽出 される.特にイソアミルアルコールにはよく抽出される が,イソアミルアルコールは水との相互溶解度が大きく, MIBK は条件によってはエマルジョンを生成しやすい ので, これらの矢点の少ないクロロホルムを溶媒とし た。

Table I キレートの抽出

\begin{tabular}{|c|c|c|c|c|c|}
\hline \multirow[b]{2}{*}{ 試 薬 } & \multicolumn{3}{|r|}{ 溶 } & \multicolumn{2}{|l|}{ 媒 } \\
\hline & ベンゼン & $\begin{array}{l}\text { クロロ } \\
\text { ホルム }\end{array}$ & 四塩化炭素 & $\begin{array}{l}\text { イソァミル } \\
\text { アルコール }\end{array}$ & MIBK \\
\hline NT & - & + & - & $H$ & $H$ \\
\hline MNT & $H$ & + & + & $H$ & $H$ \\
\hline HNT & + & + & + & $H$ & + \\
\hline PNT & $H$ & H & + & $H$ & $H$ \\
\hline MT & + & $H$ & - & $H$ & $H$ \\
\hline HMT & + & + & + & $H$ & $H$ \\
\hline $\mathrm{HCT}$ & $H$ & $H$ & H & $H$ & $H$ \\
\hline DMT & + & + & + & $H$ & + \\
\hline SNT & - & - & - & - & - \\
\hline
\end{tabular}


SNT はスルホン基を有しているためにいずれの溶媒 にも抽出されない。なお， RT 注 $\mathrm{Co}^{2+}$ とは反応する 方，こ准過ヨウ菜酸カリウムで酸化してもコバルト （III）のキレートと考えら礼るものは生放しない。

$$
4 \text { コハシルト (III) キレートの吸収曲線 }
$$

試薬深過ヨウ素酸カリウムの共存時にコバルトと反応 するよまず赤紫色になり，直ちにあざやかな緑色に変化 する・これ注，おそらくコバルト(II) キレートが先に生 成し，それが酸化されて緑色のコバルト(III) キレート になるためと考えら机る。

このキレート化合物の吸収曲線をコバルト過剩の場合 と, 試薬過剰の場合とについて測定した。

\section{$4 \cdot 1$ コバルト過剩の場合の吸収曲線}

コバルトが試薬に対して 5 倍量存在するとき生成する キレート化合物の吸収曲線を測定した.

Table II に示寸 $\mathrm{pH}$ をもつ緩衝溶液（HNT 5.98， PNT 8.01) $10 \mathrm{~m} l$ に $10^{-2} M$ コバルト溶液 $0.5 \mathrm{~m} l$, 試 薬 $1 \mathrm{ml}$, 過ヨウ素酸カリウム飽和溶液 $1 \mathrm{~m} l$ を加え, 生 成したキレート化合物をクロロホルムで抽出する。

抽出液はクロロホルムで正確に $25 \mathrm{~m} l$ にうすめ, クロ ロホルムを対照液として 350〜800 $\mathrm{m} \mu$ の吸収曲線を測 定した。

HNT, PNT のキレートは酸化が困難で HNT は加熱 してやる必要があるＰNT は加熱しても反応は完全で なく，コバルト(II) のキレートが生成しているＰNT$\mathrm{Co}$ (II) を酸化するにはいったん抽出し,有機層を過ヨウ 素酸カリウム溶液と数分間振りまぜれば, 酸化反応は完 全に進んで緑色を示すようになった，吸収曲線の測定結 果を Fig. 1，2 に示した。

\section{$4 \cdot 2$ 試薬過剩の場合の吸収曲線}

実際の定量条件で注試薬は金属に対して大過剒に加え られるので，この場合に生成しているコバルト (III) キ レートの吸収曲線を測定した。

試薬が過剩に存在しているためにキレートによる吸收 のみを正確に測定することは困難であるが，第 3 報1 と 同様に，キレート生成に使用された残りの試薬と同じ濃 度の試薬を対照液として吸収曲線を測定する方法をとっ た.コバルトと試薬とは 1:2 の比で結合していると仮 定したとき, 残存する試薬の 量を計算して 対照液とし た.

試薬 $1 \mathrm{ml}$ と適当な緩衝溶液 $10 \mathrm{ml}$ および $10^{-4} M$ コ バルト (III) 溶液 $1 \mathrm{ml}$ または $2 \mathrm{~m} l$ を添加する. $10 \mathrm{ml}$

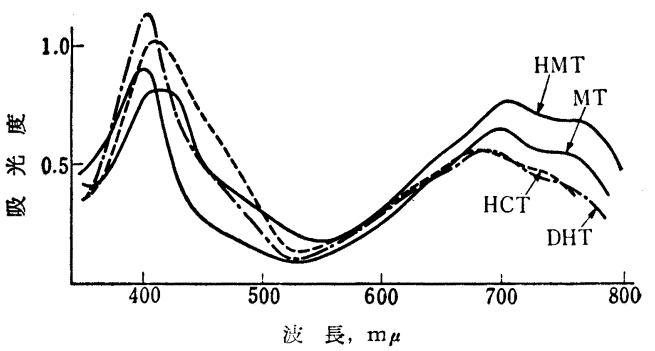

Fig. 1 コバルトキレートの财収的線 (コバルト過剰)

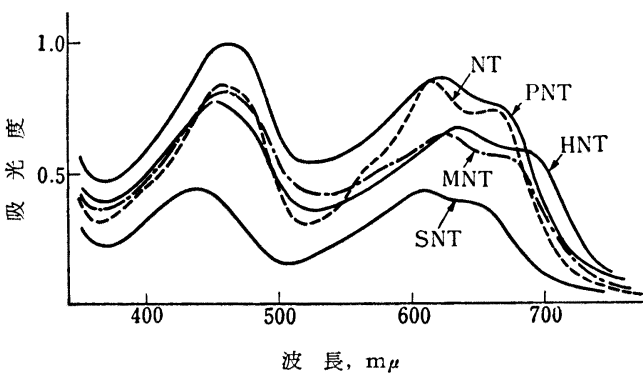

Fig. 2 コバルトキレートの吸収曲線 （コバルト過剩）

のクロロホルムで抽出する. 対照液は試薬 $0.8 \mathrm{ml}$ また は $0.6 \mathrm{ml}$ を緩衝溶液 $10 \mathrm{ml}$ に加えて, $10 \mathrm{ml}$ のクロロ ホルムで抽出艺行なったものを使用する. SNT は水溶 液中で次のようにこて測定を行なった。

緩衝溶液 $10 \mathrm{ml}$ に試薬 $2 \mathrm{ml}$ および $10^{-4} M$ コバルト (III) 溶液 $2 \mathrm{ml}$ を加えて水で正確に $25 \mathrm{ml}$ にうすめた. 対照溶液は緩衝溶液 $10 \mathrm{ml}$ に試薬 $1.6 \mathrm{ml}$ を加えて水で $25 \mathrm{ml}$ としたものを用いた。このように試薬および緩衝 溶液などに含をれている不純物による吸収を補償した結 果を Fig. 3 に示した. いずれの吸収曲線も $4 \cdot 1$ で測定 したコバルト過剩において生成しているキレート化合物 の吸収曲線と一致し，吸収の大きさから 1:2 のキレー トが試薬とコバルトとの相対的な割合に関係なく生成し ていることが推定できる。

なお，PNT，HNT 洼定量的に抽出できる条件がみつ からないので, 試薬過剩の場合の吸収曲線は測定できな かった. NT 系の $680 \mathrm{~m} \mu$ 付近の吸収帯は HNT, MNT, PNT ではNT のように極大とはならず，ゆるきかな吸 収の肩を示している. $620 \mathrm{~m} \mu$ 付近の吸収ではその極大 吸収波長注 $\mathrm{HNT}>\mathrm{MNT}>\mathrm{PNT}>\mathrm{NT}, \mathrm{HMT}>\mathrm{MT}>$ DMT $>$ HCT でほぼ試薬自体の 極大吸収波長と同一の 序列を示している。

極大吸収波長の移動注試薬に対して $100 〜 220 \mathrm{~m} \mu$ も 
長波長側に移動している. この移動は非常に大きく, 他 の金属のキレート化合物の極大吸収波長よりも 30〜100 $\mathrm{m} \mu$ も長波長側にあるので, 定量に汇他の金属による妨 害も少なく好都合である。

NT 系ではコバルト (II) キレートの極大吸收波長の移 動は少なく, 試薬のそれと重なって測定には感度をぎせ いにしなければならなかったが，コバルト(III) キレー トに与るとこの点注非常に有利である、Table II に吸 収曲線の極大吸収波長を示した。

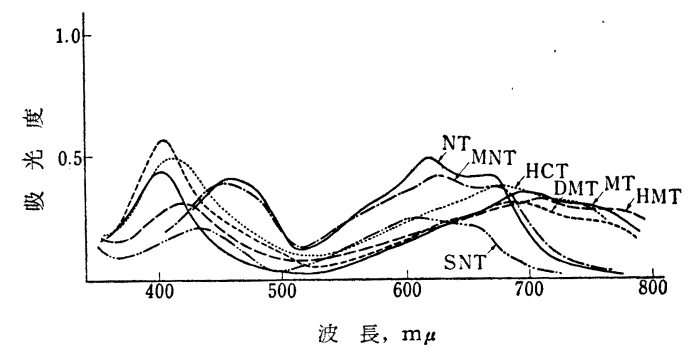

Fig. 3 コバルトキレートの财収曲線（試薬過剩）

Table II キレート化合物の極大吸収波長

\begin{tabular}{|c|c|c|c|c|}
\hline 試 蕌 & 極大吸 & 収波長 $(\mathrm{r}$ & & 測定時の $\mathrm{pH}$ 俑 考 \\
\hline NT & 665 & 618 & 459 & 5.98 \\
\hline MNT & 680 & 625 & 456 & 加 熱 \\
\hline PNT & 670 (肩) & 621 & 457 & 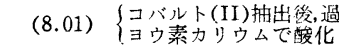 \\
\hline HNT & 680 (肩) & 636 & 454 & 加 熱 \\
\hline HMT & 760 (肩) & 706,420 , & 407 & 4.72 \\
\hline MT & & 697 & 402 & 5.98 \\
\hline $\mathrm{HCT}$ & & 682 & 415 & 4.72 \\
\hline DMT & & 687 & 406 & 4.72 \\
\hline SNT & & 610 & 437 & 水溶液 \\
\hline
\end{tabular}

\section{$5 \mathrm{pH}$ の影響}

種々の $\mathrm{pH}$ の緩衝溶液中で生成したコバルト (III) キ レートをクロロホルムで抽出し, 吸収曲線を測定し, $\mathrm{pH}$ による吸収曲線の变化, 吸光度の変化を測定し, 定量に 適当な $\mathrm{pH}$ と測定波長を求めるため検討を行なった。

$\mathrm{pH} 3.4 \sim 9.0$ の緩衝溶液 $10 \mathrm{ml}$ に試薬 $1 \mathrm{ml}$ および $10^{-4} M$ コバルト(III) 溶液 $1 \mathrm{ml}$ または $2 \mathrm{ml}$ を加えて しばらく放置するかまたは水浴上で加温したのち, $10 \mathrm{ml}$ のクロロホルムで抽出する. クロロホルムを対照液とし て 550〜750 m $\mu$ の吸収曲線を測定する. 同様にしてコ バルトを含まない混合溶液を抽出して, 試薬および不純 物による吸収曲線を求めて差引く. SNT は緩衝溶液 5 $\mathrm{ml}$ に試薬 $1 \mathrm{ml}, 10^{-4} M$ コバルト溶液 $1 \mathrm{ml}$ を加えて
水で $10 \mathrm{~m} l$ とし, 水を対照液として吸収曲線を測定し た. 測定の結果, NT 系の試薬では, 吸収の大きさが変 化しても, 吸収曲線の形には流とえど変化がなく, 同一 のキレートによる吸収と㴓められた。

HMT, HCT では明らかに吸収曲線の形が変化してい る. Fig. 4, 5 に NT および HMT の pH 変化によ る吸収曲線の変化を示した. HMTでは $\mathrm{pH}$ が高くなる と 706〜 760 $\mathrm{m} \mu$ 付近の吸収带がしだいに小さくなり, $625 \mathrm{~m} \mu$ 付近に吸収を有する曲線に移行する。ささらに高 い $\mathrm{pH}$ になると, この吸収帯も小さくなり, 試薬のみに よる吸収を示故よになった。このとき生成している $625 \mathrm{~m} \mu$ 付近に極大吸収を有するキレートはコバルト (II) キレートと考えられるので, 後でさらに詳しく検討 した。

これらを倹討の結果, 最も適当と考えられる一定の 波長で求めた吸光度と $\mathrm{pH}$ との関係蕉 Fig. 6, 7 に示 した。 HNT, PNTでは溶液を加熱しなければならな い.PNTで湖熱して子,反応は完全には進行せず，定 量的に抽出する条件はみつからなかった。

NT, SNT, HMT, MT は一定の吸光度を示寸範囲 が広く, HCT, MNT, DMT は pH が高くなると多 少吸光度が減少する傾向が表われる。加熱に上る影響は HNT, PNT, MNT に認められるが，その他の試薬で は認められない。

加熱の影響は $\mathrm{pH}$ の低い所で大きく現われる.

これらの結果より PNT, HNT は試薬として用いら れず，NT，SNT，MT 核試薬としてぐれている. HMT 注Fig. 4 に示すように極大吸収波長を用い机ば, 变化は大きいので等吸収点となる $700 \mathrm{~m} \mu$ 付近を用いた

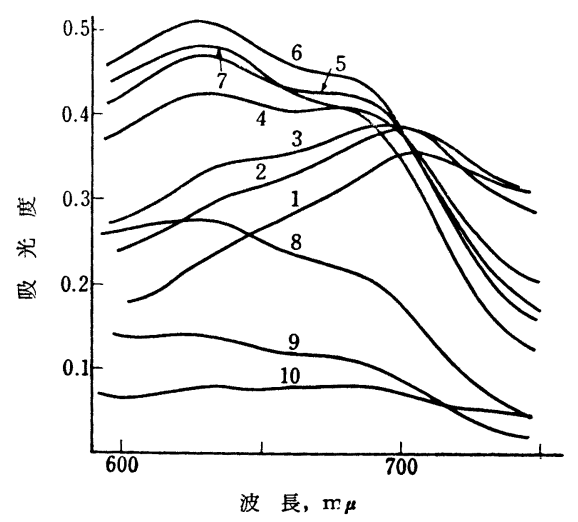

Fig. 4 コバルト-HMT キレートと $\mathrm{pH}$ $\mathrm{pH}-1 ; 3.50,2 ; 3.99,3 ; 4.72,4 ; 5.39,5 ; 5.98$, $6 ; 6.50,7 ; 6.99,8 ; 7.50,9 ; 8.01,10 ; 8.50$ 試薬溶液 $1 \mathrm{ml}, 10^{-4} M$ コパルト $2 \mathrm{ml}$ 


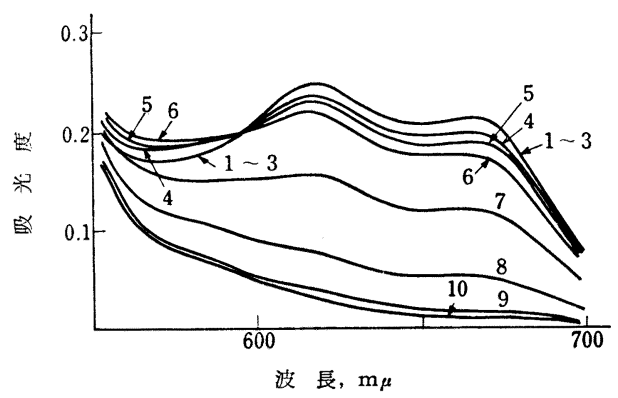

Fig. 5 コバルト-NT キレートと $\mathrm{pH}$ $\mathrm{pH}-1 ; 3.50,2 ; 3.99,3 ; 4.72,4 ; 5.39,5 ; 5.98$, $6 ; 6.50,7 ; 6.99,8 ; 7.50,9 ; 8.01,10 ; 8.50$ 試薬溶液 $1 \mathrm{~m} l, \quad 10^{-4} M$ コバルト $1 \mathrm{ml}$

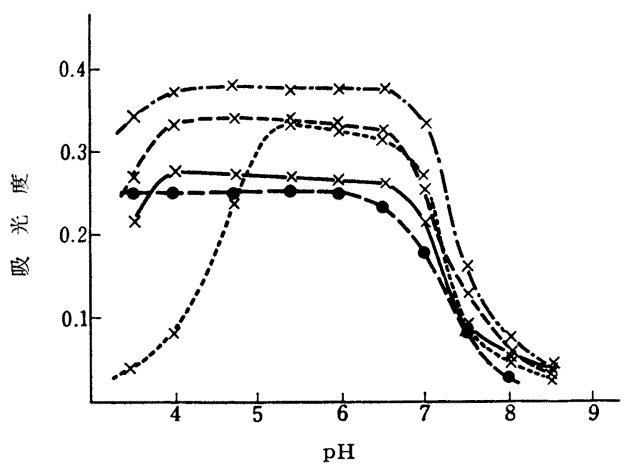

Fig. 6 抽出曲線
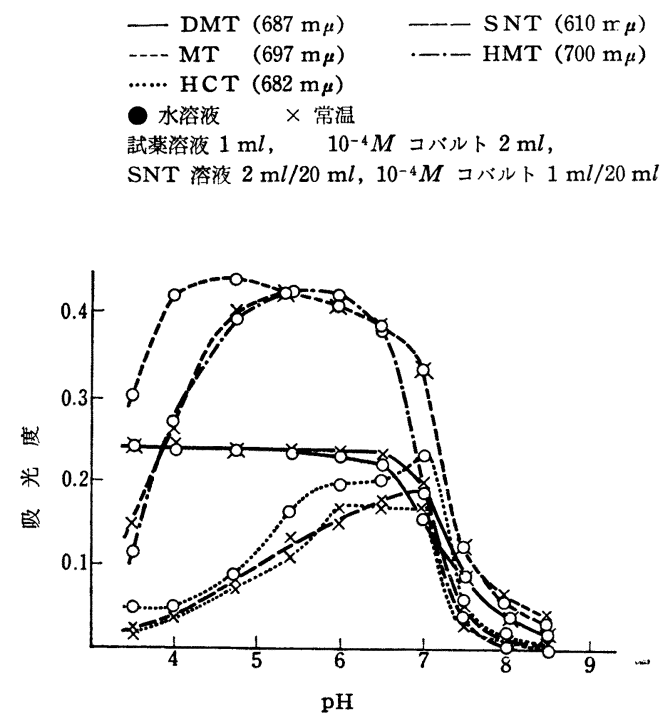

Fig. 7 抽出曲線

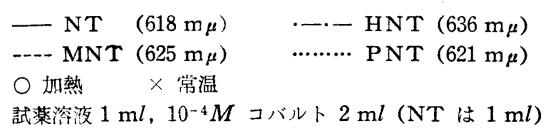

ほうがよいと考えられる・加熱操作はめんどうなので冷 時反応する条件を選び Table III のような条件を選ん だ.

Table III 定量条 件

\begin{tabular}{llc}
\hline \hline 試 薬 & $\mathrm{pH}$ & 測定波長 $(\mathrm{m} \mu)$ \\
\hline NT & 5.0 & 618 \\
MNT & 6.0 & 625 \\
MT & 5.0 & 697 \\
HMT & 5.0 & 700 \\
HCT & 6.0 & 682 \\
DMT & 5.0 & 687 \\
SNT & 5.0 & 610 \\
\hline
\end{tabular}

\section{6 組成の検討}

\section{$6 \cdot 1$ 連続変化法}

吸収曲線の測定の結果では, 1:2のキレートが生成し ていることが推定されたが, 連続変化法で組成を検討し た. $2 \times 10^{-4}$ 試薬およびコバルト(III) 溶液を合計 $3 \mathrm{ml}$ となるように採取し緩衝溶液 $10 \mathrm{~m} l$ に添加する. 少し放 置したのち $10 \mathrm{ml}$ のクロロホルムで抽出する. SNT の 場合には緩衝溶液を $5 \mathrm{~m} l$ とし, 水を加えて正確に $10 \mathrm{ml}$ とする.これらの溶液の $550 〜 750 \mathrm{~m} \mu$ 間の吸収曲線を クロロホルムまたは水を対照溶液として測定する。

測定した $\mathrm{pH}$ においてはコバルトと試薬の混合比が 1: 14〜 $5: 1$ に変化しても長波長側の吸収曲線には変化 がなく，同一キレート化合物が生成していることを示し ている. 適当な波長において測定した吸光度により連続 変化法のグラフを書くと, Fig. 8 に示すようにいずれ。 も 1:2の所にピークを有し，1:2の組成を有している ことを示している.

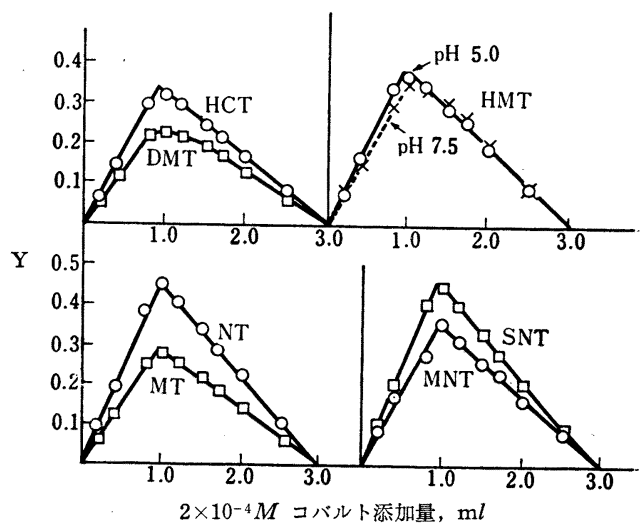

Fig. 8 連続変化法

NT $618 \mathrm{~m} \mu$, MNT $625 \mathrm{~m} \mu, \quad$ MT $697 \mathrm{~m} \mu$, HMT $706 \mathrm{~m} \mu$, НСT $682 \mathrm{~m} \mu$, DMT $687 \mathrm{~m} \mu$, $\mathrm{SNT} 610 \mathrm{~m} \mu$ (水溶液) 
HMT は特に他の試薬と異なっており, 試薬が多い場 合には $625 \mathrm{~m} \mu$ の吸収帯が $700 \mathrm{~m} \mu$ 付近の吸収より大き いが，試薬の比が小さくなるにつれて吸収の極大が 700 $\mathrm{m} \mu$ 付近の吸収より $625 \mathrm{~m} \mu$ の吸収が小さくなり，異な ったキレートが生成していると考えられるが，やはり 1:2のキレート老生成している.

\section{$6 \cdot 2$ モル比法}

NT, SNT，HMTについてさらにモル比法を用いて 組成の检討を行なった. イソアミルアルコールを抽出, 溶媒とした場合には NT, MT, CT については 1:20 組成を示していることはすでに報告したが, クロロホル ムで抽出した場合について検討を行なったＮT，SNT については次のようにして実験を行なった。 Table III に示す条件で, 試薬とコバルト (III) の混合比を変化さ せた. 試薬を $2 \times 10^{-4} M 2 \mathrm{ml}$ に固定し, コバルト(III) を $2 \times 10^{-4} M \quad 0 \sim 4.0 \mathrm{ml}$ まで变化させ, ついてコバル ト(III) を $2 \times 10^{-4} M 1 \mathrm{ml}$ に固定し, 試薬を $0 \sim 5.0 \mathrm{ml}$ まで変化させて混合し, クロロホルム抽出または水溶液 とし, 容量を $10 \mathrm{ml}$ として 450〜 750 $\mathrm{m} \mu$ の間の吸収曲 線を測定した.

この結果，いずれの場合にも吸収曲線の型は変化せず 一定の組成のキレート化合物が生成していることを示し ている. 一定の波長で混合比と吸光度との関係を示した のが Fig. 9 で，いずれも $1: 2$ に鋭い折点を有してい る.この条件では連続変化法と同様に $1: 2$ のキレート が生成していることを示している.

HMT は特に変わった現像が起っている. 高い $\mathrm{pH} に$ おいて注 $625 \mathrm{~m} \mu$ 付近に極大吸収を有する吸収曲線を示 し，これはコバルト(II) キレートとよく似ていることは すでに述べた。 pH 7.5 における試薬過剩の場合の吸収 について，このときキレートが $1: 1,1: 2$ または $1: 3$ の組成を有するものとして残存する試薬の量を計算し, それと同濃度の試薬を対照液として吸収曲線を測定し た.この結果を Fig. 10 に示した. 1:1(A)と仮定し た場合 $500 \mathrm{~m} \mu$ 付近で吸収が負になり, $1: 2$ または $1: 3$ (C)のキレートが生成しているものと考えられる. 1:2 （B）と仮定した場合の吸収曲線は Fig. 10 の（D）飞示 すコバルト(II) キレートの吸収と酷似している.また, pH 7.5 における連続変化法の結果も, モル比法による組 成の検討結果も $1: 2$ のキレートの生成を示している.

モル比の場合にも試薬が増加すると,しだいに $625 \mathrm{~m} \mu$ 付近の吸収が $700 \mathrm{~m} \mu$ 付近の吸収より大きくなって来 る. 逆にコバルトの量が多くなると $700 \mathrm{~m} \mu$ 付近の吸収 が大きくなる. 以上の結果を総合すると, HMT のコバ
ルト (III) キルートは高い pH では不安定で, コバルト (II) キレートが一部安定に存在しているものと考えられ る.

過ヨウ素酸カリウム共存下に試薬を加えた場合の変色 の様子は，まずコバルト(II) キレートを生成し，さらに 過ヨウ素酸カリウムに酸化されて 緑色のコバルト (III) になるものと考えられる.このことは PNTのコバルト (III) キレートは水溶液中では生成しにくく，いったん コバルト(II) キレートとなり, 有機層を過ヨウ素酸カリ ウム溶液で振ってはじめてコバルト (III) となるのは, このこととも関係していると考光ら机る。

これらの結果から，おそらく HMT の場合にもはじめ にコバルト(II) キレートが生成し, さらにコバルト(III) キレートに酸化されるが, $\mathrm{pH}$ が高いとコバルト(III)が 不安定になるため, 一部コバルト (II) キレートが生成し たままで存在しているものと考えられる。

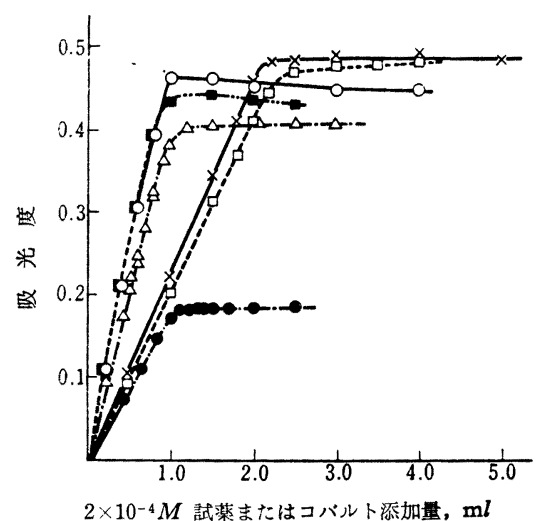

Fig. 9 モル比法
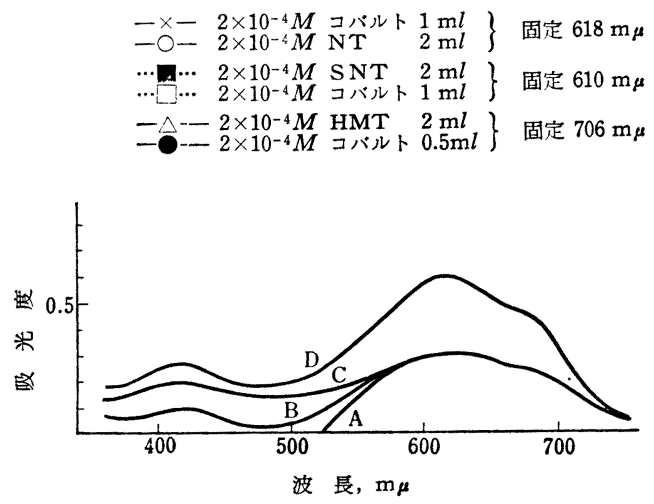

Fig. 10 コバルト (III)-HMTキレートの吸収曲線

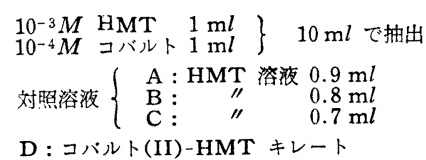




\section{$6 \cdot 3$ 等吸収点}

$2 \times 10^{-4} M$ 試薬 $2 \mathrm{ml}$ に $2 \times 10^{-4} M$ コバルト (III) 溶 液 $0 \sim 0.8 \mathrm{ml}$ および緩衝溶液 $10 \mathrm{ml}$ に加え，それぞれ $10 \mathrm{ml}$ のクロロホルムで抽出し, クロロホルムを対照液 として 450〜750 $\mathrm{m} \mu$ 間の吸収曲線を測定した. SNT は 緩衝溶液を $5 \mathrm{ml}$ とし, その他の成分は上記の場合と同 様にして混合し，水で正確に $10 \mathrm{~m} l$ にうすめ，水を対照 液として吸収曲線を測定した。この結果は Table IV に示すようにそれぞれ等吸収点を有し，この条件ではた だ 1 種のキレートが生成しており，4·2，6・1，6.2 の結 果から $1: 2$ のキレートがただ 1 種生成していることを 示している.

Table IV 等 吸 収 点

\begin{tabular}{lcc}
\hline \hline 試 薬 & 測定時の $\mathrm{pH}$ & 等棅収点 $(\mathrm{m} \mu)$ \\
\hline NT & 5.0 & 536 \\
MNT & 6.0 & 546 \\
MT & 5.0 & 553 \\
HMT & 5.0 & 554 \\
DMT & 5.0 & 525 \\
HCT & 6.0 & 521 \\
SNT & 5.0 & 543 \\
\hline
\end{tabular}

\section{7 試薬の濃度, モル吸光係数}

実際に吸光光度法でコバルトを定量する場合，どれだ け試薬を添加しなければならないかが問題となるので， その濃度の吸光度に対する影響を求め, 同時にキレート のモル吸光係数を測定した. 適当な $\mathrm{pH}$ (Table III) で $10^{-4} M$ コバルト(III) 溶液 $1 \mathrm{ml}$ に対し試薬溶液 0.5 〜 $4.0 \mathrm{ml}$ を加えてクロロホルムで抽出し, 正確に $10 \mathrm{ml}$ と して吸光度を測定し (SNT は水溶液), 試薬の吸光度拧 よび不純物による吸光度を差引いてキレートによる吸光 度を求め，モル吸光係数を測定した。この結果を Table $\mathrm{V}$ に示した.

Table V モル吸光係数, 試薬濃度の影響

\begin{tabular}{|c|c|c|c|c|c|c|c|}
\hline \multirow{2}{*}{$\begin{array}{c}10^{-3} M \\
\text { 試 薬 } \\
(\mathrm{ml})\end{array}$} & \multicolumn{3}{|r|}{ 四 } & 光 & \multicolumn{2}{|l|}{ 度 } & \multirow[b]{2}{*}{$\begin{array}{r}\text { SNT } \\
610 \mathrm{~m} \mu\end{array}$} \\
\hline & $\begin{array}{l}\text { NT } \\
618 \mathrm{~m} \mu\end{array}$ & $\begin{array}{l}\text { MNT } \\
625 \mathrm{~m} \mu\end{array}$ & $\underset{697 \mathrm{~m} \mu}{\mathrm{MT}}$ & $\underset{706 \mathrm{~m} \mu}{\mathrm{HMT}}$ & $\begin{array}{l}\mathrm{DMT} \\
687 \mathrm{~m} \mu\end{array}$ & $\underset{682 \mathrm{~m} \mu}{\mathrm{HCT}}$ & \\
\hline 0.5 & 0.225 & 0.218 & 0.147 & 0.175 & 0.146 & 0.165 & 0.254 \\
\hline 1.0 & 0.229 & 0.213 & 0.152 & 0.176 & 0.146 & 0.170 & 0.253 \\
\hline 2.0 & 0.233 & 0.211 & 0.150 & 0.175 & 0.147 & 0.165 & 0.251 \\
\hline 3.0 & 0.234 & 0.217 & 0.148 & 0.183 & 0.145 & 0.160 & 0.256 \\
\hline 4.0 & 0.229 & 0.220 & 0.150 & 0.185 & 0.147 & 0.158 & 0.253 \\
\hline $\begin{array}{l}\text { モル吸光係 } \\
\text { 数 }\left(\times 10^{-4}\right)\end{array}$ & 2.30 & 2.25 & 1.49 & 1.79 & 1.46 & 1.64 & 2.53 \\
\hline $\begin{array}{l}\text { 試薬の吸収 } \\
\left(10^{-4} M\right)\end{array}$ & 0.003 & $<0.001$ & $<0.001$ & $<0.001$ & $<0.001$ & $<0.001$ & 0.024 \\
\hline
\end{tabular}

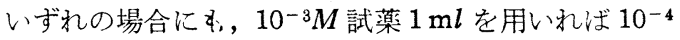
$M$ コバルト $1 \mathrm{ml}$ に対して完全にキレート化しているこ とを示している. SNT 自体の吸収注他に比して大きい が，十分実用できるものと考えられる。

Table V には試薬 $10^{-4} M$ の吸光度を同時に記載し た. モル吸光係数は $1.5 \sim 2.5 \times 10^{4}$ 程度で他のキレート に比して小さい.

\section{8 結果}

以上，コバルト (III) キレートを定量分析に用いるた わの基礎的実験の結果について述べたが，総括すると次 のようなことがいえる. NT 采ではコバルト(II) キレー トに比して長波長側の移動が大きいのでコバルト(II) キ レートの場合と異なり，極大吸収波長を測定に使用てき るので波長の誤差による吸光度の变化は少ないその他 の試薬ではコバルト(II) キレートでも十分移動が大きい ので特徴とはならない.

測定波長が相当長波長側にあるので，他の金属イオン による妨害が少なく, 試薬自体の吸収む少ないので非常 に有利である.しかし, pH の影響はコバルト(II) キレ 一トに比して大きく, NT, SNT,MTを除くとその影響 は比較的大きく，完全抽出範囲も狭くなっている．また 感度も多少小さくなっている. 従って, NT 系の試薬で はコバルト(II) キレートでは赤遷移が小さいのでコバル ト（III）として定量した注うが便利であり，妨害元素の 点を考慮するとコバルト (III) キレートのほうがよいと 考允れる.

(昭和 34 年 9 月, 本会第 8 年会にて一部発表)

\section{交献}

1) 柳原 正, 俣野宣久, 川瀬 晃: 本誌, 7,496 , 500 (1958) ; 8, 10, 14 (1959) ; 9, $344(1960)$. 川瀬 晃: 同上, $11,621,628(1962) ; 12,810$, 817 (1963). 中川元吉, 和田弘子：日化, 83, 1185 (1962).

2) 柳原 正, 俣野宣久, 川瀬 晃: 本会第 8 年会予 講集, p. 48 (1959).

$$
\text { is }
$$

Determination of cobalt(III) with o-(2-thiazolylazo) phenol derivatives. Akira KAwASE (National Research Institute for Metals, Meguro-ku, Tokyo) $o$-(2-Thiazolylazó) phenol derivatives reacts with cobalt and form green chelates in the presence of potassium periodate. They have limited solubilities in water but can be extracted readily with chloroform.

Their chloroform solutions showed maximum absorptions at $600 \sim 700 \mathrm{~m} \mu$ (Fig. 1 and 2 , and Table II), and their molar extinction coefficients were $1.5 \sim 2.5 \times 10^{4}$ (Table V). 
As the maximum absorption of the cobalt (III) chelate is shifted to the longer wavelength from those of the other chelates, there is less disturbance by the presence of other metal ions.

The constitutions of chelates (Fig. 8 and 9) and the effects of $\mathrm{pH}$ (Fig. 4 7) have been investigated and the conditions for determination of cobalt have been established.

(Received May 6, 1963)

\title{
高分子量アミンによる金属の臭化水素酸溶液からの抽出
}

\author{
鈴木 俊雄, 外林 武*
}

\begin{abstract}
N-ドデセニルトリアルキルメチルアミン(Amberlite LA-1)の 10\% キシレン溶液を用いて臭化水素 酸溶液からの鉄 (II, III), コバルト, ニッケル, 要鉛, 鉛, スズ (IV), カドミウム, ビスマス, ガリ ウム礼よびインジウムの抽出について研究した。てれら金属イオンのうち鉄(III), コバルト,ニッケル, 西鉛扣よびスズ (IV) の抽出性は塩酸系と類似性を示すが，鉄(II) は塩酸系よりも抽出率が全体的に低 く，逆に鉛とカドミウムは抽出率がはるかに高く，特にカドミウムは塩酸系に比べて非常に低い酸蕽度 まで抽出が完全である.ガリウムは塩酸系より高い酸濃度で抽出が始まり，低い酸濃度 $(<2.5 N)$ では ほとんど抽出されない。一方，インジウムは塩酸系と異なり，比較的低い酸濃度からも高い抽出率を示 し, 高い酸濃度でも抽出率は減少しない. この抽出性の差を利用してガリウムとインジウムの相互分離 を試みたところ，非常に良好な結果を得た。
\end{abstract}

\section{1 緒言}

液状陰イオン交換体とも考えられる高分子量アミンに よる金属錯陰イオンのイオン交換抽出について多数の研 究が行なわれ，特に最近金属イオンを塩素錯イオンとし 塩酸溶液から抽出する報告が多(1) 8)。著者らは, 第二 アミンである $\mathrm{N}$-ドデセニルトリアルキルメチルアミン (Amberlite LA-1) を用いて，主な金属イオンを臭素 錯イオンとし, 臭化水素酸溶液から抽出した結果を塩酸 溶液からの抽出性と比較検討してみた.その結果，分析 化学的に二, 三の興味ある結果が得られたのでここに報 皮する.

\section{2 実験}

\section{$2 \cdot 1$ 試薬と装置}

アミン溶液 : Amberlite LA-1 をキシレンに溶かし10 vol\% 溶液こしたのち，水で十分洗って水溶性の不純物 を除いておく、なお，アミン溶液を使用する前に $1 N$ 臭 化水素酸々振ってアミンの臭化水素酸塩溶液として用い る.

鉄 (II) 標準溶液 : 特級硫酸第一鉄アンモニウム一定量 を希臭化水素酸に溶かし，鉄として $3.24 \mathrm{mg} / \mathrm{ml}$ とす る.な打使用の際，あらかじめアスコルビン酸を少量加 え，完全に鉄(II) 亿還元してから使用する.

* 新潟大学理学部化学教室 : 新潟市西大畑町
鉄(III), 鉛, ビスマス, スズ (IV), ガリウム扰よび インジウム標準溶液 : 硫酸第二鉄アンモニウム, 硝酸鉛, 硝酸ビスマス, 塩化第二スズ, 金属ガリウム打よび塩化 インジウムをそれぞれ水または酸に溶かし金属塩溶液と し，乙れに希アンモ二アを加えそれぞれの水酸化物沈殿 をつくる. 沈殿を口過, 洗浄したのち, これを希臭化水 素酸に溶かし，それぞれの標準溶液とする。な抏，それ ぞれの金属イオン濃度をEDTA 標準溶液で滴定して, 鉄 $3.81 \mathrm{mg} / \mathrm{ml}$, 鉛 $10.24 \mathrm{mg} / \mathrm{ml}$, ビスマス 14.42 $\mathrm{mg} / \mathrm{ml}$, スズ $4.26 \mathrm{mg} / \mathrm{ml}$, ガリウム $3.46 \mathrm{mg} / \mathrm{ml}$, インジウム $2.61 \mathrm{mg} / \mathrm{ml}$ となった.

ニッケル，コバルト，銅，カドミウムおよび亜鉛標準 溶液: 硫酸ニッケル, 硝酸コバルト, 硫酸銅, 硝酸カド ミウム打よび金属亚鉛をそれぞれ水または酸に溶かし， これに水酸化ナトリウム溶液を加え（亜鉛溶液には過剩 に加えないこと），それぞれの水酸化物を沈殿させる. 沈殿を口過, 洗浄したのち, 乙れを希臭化水素酸に溶か し標準溶液とする。な打 EDTA 滴定により, ニッケル $3.93 \mathrm{mg} / \mathrm{ml}$, コバルト $3.78 \mathrm{mg} / \mathrm{ml}$, 銅 $3.67 \mathrm{mg} / \mathrm{ml}$, カドミウム $5.60 \mathrm{mg} / \mathrm{ml}$, 亜鉛 $3.67 \mathrm{mg} / \mathrm{ml}$ の金属イ オン濃度となった.

臭化水素酸 : 関東化学特級臭化水素酸 $(d=1.48)$ を 使用した。

その他の試薬はなるべく特級品を使用した。

分液口ートは容量 $80 \mathrm{ml}$ の細型のものを使った。

\section{$2 \cdot 2$ 実験法}

金属標準溶液 1 $2 \mathrm{ml}$ を分液ロートにとり，これに一 